\title{
Jorge Amado, o realismo socialista e o romance proletário: historiografia e crítica literária (1931-1937)
}

Jorge Amado, socialist realism and proletarian romance: historiography and literary criticism (1931-1937)

\author{
Geferson Santana*
}

Resumo: $\mathrm{O}$ artigo tem o intuito de refletir sobre as obras de Jorge Amado entre os anos de 1931 a 1937. Daremos atenção especial para aquilo que o escritor denominou de romance proletário, o que exigiu um estudo dos modelos estéticos que foram tomados como referentes em sua produção literária. Para alcançar nosso objetivo, empreendemos um trabalho de análise crítica e fizemos um cruzamento entre os principais estudos historiográficos sobre a produção literária amadiana e as narrativas que foram construídas pelos críticos literários brasileiros e estrangeiros (fortuna crítica) que se debruçaram sobre a produção intelectual amadiana.

Palavras-chave: Crítica literária, História e literatura, Jorge Amado, romance proletário.

Resumen: El artículo tiene el propósito de reflejar sobre las obras de Jorge Amado entre los años de 1931 y 1937. Daremos especial atención para lo que el escritor ha llamado como romance proletario, el que exigió un estudio de los modelos estéticos que se han tomado como referencia en su produción literaria. Para alcanzar nuestro objetivo, empreendemos un trabajo de analisis crítico y cruzamiento entre los principales estudios historiográficos sobre la producción literaria amadiana y las narrativas que fueron construidas por los críticos literarios brasileños y extranjeros (fortuna crítica) que se enclinaron sobre la producción intelectual amadiana.

Palabras clave: Crítica literaria, História y literatura, Jorge Amado, romance proletário.

Recibido: 8 julio 2018 Aceptado: 23 octubre 2018 
O escritor Jorge Amado morou em Ilhéus, região cacaueira do sul da Bahia, para onde se mudou quando tinha apenas um ano de idade. Era "filho do Coronel João Amado' de Faria e da Senhora Eulália Leal Amado, nasceu em 1912, na fazenda Auricídia, em Ferradas, distrito de Itabuna, sul da Bahia"2. Sua família passou por problemas financeiros e, devido a isso, seu pai chegou a ser tamanqueiro para sobreviver. Em "seguida, junto à família, vai morar na Fazenda Taranga, em Itajuípe, Bahia, em 1917, vindo a ocupar-se do cultivo do cacau"3.

Estudou no Colégio Antônio Vieira, de influência jesuítica, locado na cidade de Salvador. O colégio em associação a outros como Carneiro Ribeiro, Colégio Ipiranga e Ginásio da Babia, foi responsável pela "formação intelectual dos membros das elites baianas"4. Segundo o historiador Paulo Santos Silva, foi a instituição de ensino secundário de maior destaque na capital 5 . Ainda na referida escola, Amado sofreu a influência do padre Luís Gonzaga Cabral - orador sacro, homem muito culto e português de nascimento ${ }^{6}$. A admiração de Amado pelo padre foi realmente marcante em sua trajetória ${ }^{7}$.

O professor Luís Gonzaga Cabral foi quem percebeu a vocação literária de Amado. O docente estava substituindo o professor Faria, que na visão de Amado, não tinha vocação para o ofício e muito menos para ensinar regras gramaticais. O escritor qualificou o professor titular da matéria como uma figura limitada ${ }^{8}$. Sobre o substituto, disse Amado: "Então, ele fazia uma coisa que lhe agradava e agradava imenso a gente. Ele vinha e lia textos de livros, de Camões, por exemplo"9.

A admiração pelas aulas do professor substituto não impediu Jorge Amado de fugir daquele estabelecimento. Ele ficou no colégio de orientação religiosa entre 1923 a 1924, e na volta às aulas do ano seguinte pediu a João Amado que não o enviasse à escola, porém o pedido não foi atendido. Nas entrevistas que consultamos, percebemos que Amado não gostava da rigidez escolar, onde sua liberdade era cerceada ${ }^{10}$.

Quando estava na porta do colégio, fugiu para Sergipe onde residia seu avô. A viagem durou dois meses, e logo ficou sem dinheiro. Chegando em Sergipe, ficou alguns dias, e logo seu pai mandou o tio Álvaro buscá-lo. Quando retornou confessou ao pai que não queria mais estudar, sendo aquele o motivo da fuga. Acabou retornando, e ficou seis meses na fazenda do avô ${ }^{11}$.

\footnotetext{
* Brasileiro, Doutorando em História Econômica pela Universidade de São Paulo (USP). Este artigo é resultado da pesquisa de mestrado em História pela Universidade Federal de São Paulo (UNIFESP), sob o financiamento da Fundação de Amparo à Pesquisa do Estado de São Paulo (FAPESP). Correio eletrônico: santanageferson@gmail.com

1 “O pai, João Amado de Faria, sergipano de Estância, irmão de Melchisedech Amado (pai dos Amados de Sergipe, todos êles destacados no cenário cultural ou social do país: Gilberto, Gildásio, Gildo, Gennyson, Genolino, Gilson, Guiseppe, Gileno), fôra caixeiro de um armazém de secos e molhados, dos 10 aos 20 anos. Em 1902, emigrou para Ilhéus, levando de seu, no bolso, meio conto de réis, e na determinação um desejo, mais tarde realizado, de tornar-se fazendeiro. Com a cheia do rio Cachoeira, em 1914, perdeu tudo que tinha e padeceu miséria. Até 1918 exerceu, na cidade de Ilhéus, oficio de tamanqueiro, com residência no bairro de Pontal, auxiliado pela espôsa, D. Eulália Leal Amado, sertaneja baiana de Amargosa, cuja família, em busca de fortuna, emigrara, como o fizera João Amado, para a zona do cacau”. TÁTI, Miécio. Jorge Amado: vida e obra. Belo Horizonte: Editoria Itatiaia Limitada, 1961. p. 17-18.

2 AMADO, Jorge; GOMES, Alvaro Cardoso. Jorge Amado. São Paulo: Abril Educação, 1981. p. 4; Cf. SOARES, Ângelo Barroso Costa. Academia dos Rebeldes: modernismo à moda baiana. 2005. 207 f. Dissertação (Mestrado em Literatura e Diversidade Cultural) - Universidade Estadual de Feira de Santana, Feira de Santana, 2005.

3 TÁTI, op. cit., p. 17-18.

${ }^{4}$ SILVA, Paulo Santos. Âncora de tradição: luta política, intelectualidade e construção do discurso histórico na Bahia (19301945). Salvador: EDUFBA, 2000. p. 80.

${ }_{5}^{5}$ RAILLARD, Alice. Conversando com Jorge Amado. Rio de Janeiro: Record, 1992. p. 31; SILVA, op. cit., p. 80.

6 TÁTI, op. cit., p. 15-16; AMADO; GOMES, op. cit., p. 7.

7 Disse: "lá conheci um homem incrível, o padre Cabral, nosso professor de Português; ele me emprestava livros, fez-me descobrir As viagens de Gulliver, Dickens, que é até hoje um dos meus autores preferidos, e isso ajudou a suportar aquele universo rígido". SILVA, op. cit., p. 80-81.

8 AMADO; GOMES, op. cit., p. 7.

9 Idem.

10 RAILLARD, op. cit., p. 31.

11 AMADO; GOMES, op. cit., p. 8-9.
} 
Em início de 1926, Amado ingressou no Ginásio Ipiranga, dirigido por Isaías Alves de Almeida, como uma espécie de castigo por ter fugido da escola anterior ${ }^{12}$. Pelo menos no colégio novo tinha mais liberdade. Conseguia pular o muro e ter seus momentos de liberdade pelas ruas de Salvador. Sem contar que naquela escola exerceu a função de escritor, como deixou bem claro na entrevista, e ajudou na fundação de dois jornais: $A$ Folha e $A$ Pátria ${ }^{13}$.

Os ginásios eram poucos e os mais destacados ficavam situados na capital. Municípios como Alagoinhas, Nazaré, Santo Amaro, Jequié e Lençóis, na Bahia, tinham escolas ginasiais, mas em números escassos ${ }^{14}$. Devido ao pouco número de instituições de ensino nesse nível, alguns começavam a estudar com professores particulares, os chamados mestres-escolas ${ }^{15}$.

Amado ingressou no Partido Comunista do Brasil (PCB) por intermédio da relação de amizade que tinha com a escritora cearense Rachel Queiroz ainda nos primeiros anos da década de 1930. Isso o colocou numa posição de destaque no partido, pois assumiu a função de ser o principal promotor do romance proletário no Brasil, conforme as orientações da União das Repúblicas Socialistas Soviéticas (URSS) ${ }^{16}$. Reitera-se ainda, que a amizade com a escritora cearense rendeu a participação de Amado na Juventude Comunista (JC), que era uma das atividades ilegais do partido, o que gerou perseguição da polícia e batidas policiais nos locais de encontro do grupo ${ }^{17}$.

$\mathrm{O}$ staff do escritor Amado reunia vários críticos e escritores vinculados ao PCB, comprometidos em (re)afirmar o caráter proletário, revolucionário, moderno e documental de seus romances ${ }^{18}$. Segundo a historiadora Carine Dalmás, podemos notar tal aspecto a partir da criação do jornal $A$ Manbã, nascido do movimento de caráter antifascista e comunista da Aliança Nacional Libertadora (ANL), uma vez que ambos pareciam seguir as orientações soviéticas para a produção artístico-literária ${ }^{19}$.

Mas, quais eram as diretrizes da URSS para os PCs? Como tais elementos podem ser percebidos no romance proletário amadiano? O jornalista Alberto Passos Guimarães, comunista desde 1932, num artigo para o Boletim de Ariel respondeu à pergunta do prefácio do livro: "Será um romance proletário?"20. Disse:

Ao meu ver, é. Embora impressionado mais pelo aspecto sentimental do problema, até a ligação afetiva do Sergipano, embora misturando algumas vezes as situações puramente morais com os sentimentos rebeldes da gente do campo, "Cacau" exala um bom ar de revolta para estar junto da literatura proletária. (...) Em "Cacau" tem-se bem a paisagem dos nossos campos semi-bárbaros, das nossas fazendas, onde a ruindade dos feudos se conserva com o mesmo ardor. (...) "Cacau" é um romance proletário. ${ }^{21}$

O escritor baiano João Cordeiro veio em defesa da obra. Ele a considerou um grande romance, porque Amado não criou uma "piedade burguesa" pelos miseráveis daquela terra, e optou por mostrar

\footnotetext{
12 TÁTI, op. cit., p. 16; RAILLARD, op. cit., p. 31.

13 AMADO; GOMES, op. cit., p. 7.

14 SILVA, op. cit., p. 79.

15 Termo usado na época e mantido por Silva na pesquisa. Idem.

16 DALMÁS, Carine. Frentismo cultural dos comunistas no Brasil e no Chile: literatura, escritores e virada aliancista (19351936). Projeto História, São Paulo, n. 47, p. 228, ago. 2013.

17 RAILLARD, op. cit., p. 48-49.

18 Ver debate em: SANTANA, Geferson. O combate das ideias: estratégias culturais dos intelectuais comunistas baianos na produção de um novo conhecimento sobre o Brasil (1920-1937). 2017. 336 f. Dissertação (Mestrado em História) Universidade Federal de São Paulo, Guarulhos, 2017.

19 DALMÁS, op. cit., p. 233 e 229.

20 AMADO, Jorge. Cacau. Rio de Janeiro: Record, 1981. p. 8.

21 GUIMARÃES, Alberto Passos apud AMADO, Jorge (Org.). Jorge Amado: 30 anos de literatura. São Paulo: Livraria Marins Editoria, 1961. p. 76-77.
} 
o sofrimento, estigma, revolta latente. Para Cordeiro, aí reside um dos motivos para ter admiração pelo romance que considerou ser "um livro de combate", posto que o "cacau encontrou, enfim, o seu romancista"22. O escritor francês Max-Pol Fouchet, que também atuou no Partido Socialista francês, chegou a corroborar a reflexão de Cordeiro, ao afirmar que é um livro "engagé, Cacao est un livre de combat, écrit par un auteur qui ne craint pas, au début, de poser cette question: Sera-t-il sorti de là un roman prolétaire?"23.

Murilo Mendes, num artigo publicado no periódico Boletim de Ariel, escolheu problematizar em torno da ideia de "romance proletário" atribuída ao romance por seu próprio autor. Explicou que a "mentalidade" proletária ainda estava em processo de formação, e não tem total consciência de seu papel histórico. Acrescentou que os escritores que encontrarem inspiração na vida em decomposição da sociedade burguesa terão que voltar-se para o proletariado, encontrando aí não apenas material para a construção do romance, como as ferramentas para integrar ao "espírito do proletariado" e tornar-se um escritor revolucionário ${ }^{24}$.

Mendes ainda esclareceu ser impossível fazer um romance de tom proletário sem estar integrado ao mundo proletário, pois não basta apenas ser um "observador", mas fazer parte, pois aí moraria o caráter revolucionário do escritor. Sem isso, correria o risco de fazer "simples reportagem". Segundo ele, Amado foi quem mais se aproximou da ideia de "romance proletário", ao contrário de Patrícia Galvão (Pagu), que em Parque Industrial (1932) cometeu um engano:

"Romance proletário", anuncia a autora no frontispício do Parque Industrial. Houve engano. É uma reportagem impressionista, pequeno-burguesa, feita por uma pessoa que está com vontade de dar o salto, mas não deu. Assiste-se à entrega de fábricas, à saída de fábricas, a encontros do filho do grande capitalista com a filha do operário, etc. Parece que para a autora o fim da revolução é resolver a questão sexual. Sôbre o Parque Industrial pròpriamente pouca coisa se fica sabendo. ${ }^{25}$

O segundo romance de Amado, somado aos demais da década de 1930, representou um esforço em constituir uma obra inscrita dentro da perspectiva do "romance proletário". Mas, quais leituras foram tomadas como referência para a construção de um corpo literário dentro dessa estética? Não existem muitos estudos aprofundados sobre as leituras feitas por Jorge Amado. Analisar o conteúdo dessas obras nos permitiria entender melhor as verdadeiras aproximações entre o tipo de romance proletário construído pelo autor e sua relação com os romances estrangeiros.

Miécio Táti listou alguns livros de escritores russos e de outras nacionalidades que estiveram presentes na vida literária de Amado, como Judeus sem dinheiro, de Michael Gold. Inclusive, disse o escritor baiano, que o volume citado fez muito sucesso e influenciou muitos escritores ${ }^{26}$. Aos nomes citados anteriormente podemos acrescentar "Ostrovski (Torrente de Ferro), Cholokhov, Fadeiev(A Derrota), Isaac Babel (Cavalaria Vermelha), Pliniak, Ilya Ehrenburg (Júlio Jurenito)" 27. Os livros enumerados foram traduções lançadas pela Editorial Pax, que era financiada por Carlos Prestes e

\footnotetext{
22 CORDEIRO, João apud Ibidem, p. 73.

${ }^{23}$ FOUCHET, Max-Pol apud Ibidem, p. 76.

${ }^{24}$ MENDES, Murilo apud Ibidem, p. 72.

25 Idem apud Ibidem, p. 72.

26 SECCO, Lincoln. Leituras comunistas no Brasil (1919-1943). In: DEAECTO, Marisa Midori; MOLLIER, Jean-Yves (Orgs.). Edição e revolução: leituras comunistas no Brasil e na França. Cotia, São Paulo: Ateliê Editorial; Belo Horizonte, Minas Gerais: Editoria UFMG, 2013. p. 56.

27 AMADO; GOMES, op. cit., p. 13. Para uma consultar de outros pesquisadores que tentaram entender o itinerário de autores lidos por Amado, ver: DUARTE, Eduardo de Assis. Jorge Amado: romance em tempo de utopia. Natal: Editora da UFRN, 1995.
} 
funcionava na rua Libero Badaró, em São Paulo ${ }^{28}$. Lincoln Secco esclarece-nos que o PCB foi importante na introdução da nova literatura no país, por meio de suas poucas livrarias ${ }^{29}$.

$\mathrm{Na}$ entrevista que Amado cedeu à Alice Raillard ficou evidente que ele leu o romance alemão Passageiros de Terceira Classe de Kurt Klaber por considerá-lo um romancista proletário. O escritor baiano expõe que viu em Klaber uma esperança para o modelo estético literário que se propunha a escrever. Quando esteve na Europa, ele buscou pistas do romancista alemão, e descobriu apenas que, com a ascensão do nazismo, "estabeleceu-se na Suíça, e lá o citado 'romancista proletário' transformou-se num autor de best-sellers para mocinhas, gênero Delly... Na hora abandonei as minhas pesquisas" 30 . Independente do caminho tomado por Kurt Klaber, acreditamos que foi um dos que mais marcaram Amado.

Os debates sobre romance proletário, tem uma relação direta com o realismo socialista, enquanto uma estética que marcou os romances do escritor baiano, tendo em vista que era uma das orientações aos intelectuais vinculados ao partido. O realismo da literatura russa foi apresentado no discurso de Andrei Zhdanov, no I Congresso de Escritores Soviéticos, ocorrido entre os dias 17 de agosto e 01 de setembro de 1934, em Moscou. Zhdanov foi do Partido Comunista da União Soviética (PCUS) e braço direito de Josef Stalin. Seu discurso no congresso esteve respaldado nas conquistas da "nova sociedade soviética"31.

Para Zhdanov, o I Congresso protagonizado por escritores russos - como Maxim Gorky, Karl Radek, Nikolai Bukharin e A. I. Stetsky - representou a vitória das doutrinas de Karl Marx, Friedrich Engels, Vladimir Ilitch Lenin (Lenin) e Stalin e tais doutrinas deveriam servir como armas na luta contra o capitalismo 32 .

No discurso de Zhdanov consta que aos poucos o proletariado arregimentava os seus escritores. Muitos deles pertencentes a países capitalistas, que inclusive, se encontravam em processo de "decadência"33. A literatura russa tinha papel importante na construção socialista, e caberia aos escritores ou engenheiros da alma bumana ${ }^{34}$, como os denominou Stalin, construir suas narrativas nos feitos heroicos, épicos. Explana o historiador Víctor Augusto Piemonte, que após o triunfo da revolução bolchevique, o governo proclamou que o "que llama intelligentsia es uno de los tres pilares del orden socialista, junto con el proletariado y el campesinato" 35 . Ou seja, os escritores ganharam função imprescindível na nova ordem que se estabeleceu ao assumir a função de "porta-voz do gênero humano, arte, vida e pensamento [...]"36.

O russo Zhdanov afirmou que caberia aos escritores conhecer a vida, a ponto de poder representá-la nas obras. Não apenas como simples representação da realidade objetiva, como mostrar a

\footnotetext{
${ }_{28}$ TÁTI, op. cit., p. 40; SECCO, op. cit., p. 55.

29 Idem.

${ }^{30}$ RAILLARD, op. cit., p. 56.

31 O congresso foi fruto de um processo de transformações sociais, políticas, econômicas e culturais da sociedade soviética. Com a extinção da Associação de Escritores Proletários Russos (RAPP), por Stalin devido a sua orientação trotskista, o governo russo criou a União dos Escritores Soviéticos com intuito de oficializar uma nova política cultural.

32 ZHDANOV, Andrei. Soviet Literature - Richest in Ideas, Most Advanced Literature. In: Gorky, Radek, Bukharin, Jdanov and others "Soviet Writers' Congress 1934", Lawrence \& Wishart, 1977. Transcribed by Jose Braz, Andy Blunden and Hasan. p. [décimo e décimo primeiro parágrafos].

33 NAPOLITANO, Marcos. A relação entre arte e política: uma introdução teórico-metodológica. Temáticas, Campinas, v. 37, n. 38, p. 47, 2011.

34 Termo usado pelo russo Zhdanov.

35 PIEMONTE, Víctor Augusto. El realismo socialista, la Tercera Internacional y el giro político-cultural en el comunismo argentino. In: Jornadas de Sociología de la UNPL, 7., 2012, Argentina. Anais Eletrônicos.... Argentina: UNPL, Argentina. p. 8.

36 DIAS, Fabio Alves dos Santos. Do realismo burguês ao realismo socialista: um estudo sobre a questão da herança cultural no pensamento de Lukács nos anos 1930. 2014. p. 298. Tese (Doutorado em Sociologia) - Universidade de São Paulo, São Paulo, 2014.
} 
realidade em seu pleno desenvolvimento revolucionário. No entendimento do autor, a nova postura permitiria educar ideologicamente o trabalhador dentro do espírito socialista, residindo aí a finalidade do realismo socialista ${ }^{37}$. Conforme a pesquisadora Daiana Nascimento dos Santos, a "arte debía ser accesible a las masas y tener un propósito social en que legitimase el progreso socialista; exigía del escritor veracidad y una representación concreta de la realidad revolucionaria"38.

Era necessário que os escritores tivessem uma concepção inteiriça e madura do mundo, posto que "precisa ver o mundo na sua contrariedade móvel, para solucionar como protagonista um ser humano em cujo destino se cruzem os contrários"39. Santos e Lukács entenderam que a concepção de mundo do escritor deveria estar respaldada em experiências concretas ${ }^{40}$. Ou seja, sem "uma concepção do mundo não se pode narrar bem, isto é, não se pode alcançar uma composição épica ordenada variada e completa" 41 .

O realismo socialista, a partir de 1932, passou a ser encarado como um método que tinha o papel de descrever o real, como se fosse uma cópia do mesmo. A busca pelo real tem por fim a educação dos proletários, fazendo despertar a consciência de classe e o espírito do socialismo. Ou seja, a arte soviética de cunho realista assumiu função dupla: caráter pedagógico e entretenimento ${ }^{42}$. Em outras palavras, o escritor não deveria ser apenas aquele que descreve. A produção artística deve expressar a relação prática do autor com a realidade à qual delineia. Os intelectuais deveriam expor seus posicionamentos políticos, como representar na obra o "punto de vista de la classe obrera el que debía ser abordado por el realismo socialista" 43 .

O que demonstraremos é que Amado assumiu o caráter político-partidário dos romances, até porque em sua interpretação, já havia desaparecido o "homem sem partido. Hoje ele é tão raro como um animal pré-histórico" 44 . Ou, para fazer menção ao escritor russo Ilya Ehrenburg, só a literatura que toma partido teria o poder de fazer compreender a grandiosidade da luta do proletariado ${ }^{45}$. Ao assumir o realismo socialista como modelo estético, Amado acabou por direcionar seu olhar para a vida cotidiana e os sofrimentos dos trabalhadores baianos, inclui-se as proletárias, e ao mesmo tempo, esteve comprometido em usar uma linguagem que permitisse ser compreendido pelo proletariado e pelos pares.

Na acepção de Eduardo de Assis Duarte e Daiana Nascimento dos Santos, não há dúvidas que a obra amadiana está envolta pelo manto político-ideológico do PCB e do realismo socialista soviético. Afirma Santos, que as posturas ideológicas do escritor baiano estão expressas pela estética do romance proletário em "sus textos iníciales: Caca (1933), Suor (1934), Jubiabá (1935), luego del Realismo Socialista en Seara Vermelha (1946) y en la trilogía Os Subterrâneos da liberdade (1954)"46. Nesse sentido:

\footnotetext{
${ }^{37}$ NAPOLITANO, op. cit., p. 45.

38 SANTOS, Daiana Nascimento dos. El realismo socialista en tierras tupiniquines. Pacarina del Sur, ano 5, n. 21, out./dez., 2014. Disponível em: http://pacarinadelsur.com/home/figuras-e-ideas/1030-el-realismo-socialista-en-tierras-tupiniquines. Acesso em: 21 jul. 2018.

${ }^{39}$ LUKÁCS, Georg. Ensaios sobre literatura. Rio de Janeiro: Editora Civilização Brasileira, 1965. p. 78.

40 SANTOS, El realismo socialista en tierras tupiniquines.

${ }^{41}$ LUKÁCS, op. cit., p. 80.

42 NAPOLITANO, op. cit., p. 45; PIEMONTE, op. cit., p. 8-9.

43 PIEMONTE, op. cit., p. 10.

44 TÁTI, op. cit., p. 57.

45 EHRENBURG, Ilya apud MARIÁTEGUI, José Carlos. Revolução Russa: história, política e literatura. São Paulo: Expressão Popular, 2012. p. 139.-

46 SANTOS, El realismo socialista en tierras tupiniquines; SANTOS, Daiana Nascimento dos. Hoz, martillo, resistencia, sudor y pueblo en el brasileño Jorge Amado. In: CUNHA, Betina Ribeiro Rodrigues da; REIS, Carlos (Orgs.). Amado Jorge: um retrato de muitas faces. Rio de Janeiro: Bonecker, 2018. p. 39-40. Ainda Cf. SANTOS, Daiana Nascimento dos. Comunismo y Novela en el brasileño Jorge Amado. Izquierdas, Santiago de Chile, ano 3, n. 6, p. 1-5, 2010. Ainda conferir este debate em: DUARTE, op. cit., p. 30, 45, 91 a 145.
} 
Jorge Amado, por su parte, se apropia de temáticas relacionadas a la literatura proletaria rusa, en la medida en que propone reemplazos significativos para legitimar esta estética en el territorio brasileño. Ahora bien, las sustituciones contextuales percibidas en la narrativa de Cacau, Suor y Jubiabá comprueban este discurso del escritor de adecuación de temáticas socialistas al imaginario brasileño ${ }^{47}$.

Santos traz reflexões inovadoras para o campo de análise das obras amadianas publicadas nas cinco primeiras décadas do novecentista. O fragmento supracitado deixa claro que Amado apropriou-se dos elementos culturais das diversas comunidades soteropolitanas para posicionar-se politicamente e legitimar um "fazer literário" no cenário intelectual brasileiro dos anos de 193048. Ao mesmo tempo, essa produção estava sob a supervisão dos dirigentes do PCB que "exigían inflexiblemente a la intelectualidad comunista que siguiera rigurosamente las directrices del realismo socialista, imitando los modelos importantes del arte literario soviético"49.

Nos romances que nos dispomos a analisar, assim como sua fortuna crítica, não podemos desconsiderar que os trabalhadores baianos são personagens centrais ao longo da narrativa ${ }^{50}$. E curioso que Amado arrolou como personagens-trabalhadores as meretrizes, pescadores e mendigos que, à época, não eram considerados pelos demais setores sociais, como tais ${ }^{51}$. Santos está certa ao afirmar que o escritor baiano elegeu o "povo" como seu principal sujeito, dando a este uma "nova cara" 52 . Mas a autora não faz uma análise aprofundada desses sujeitos que compõem a categoria ou nomenclatura "povo". Algumas questões podem ser levantas, como: Quais são os sujeitos que compõem o "povo"? Como poderíamos conceituar tal terminologia? A autora pensou nos sujeitos-personagens que tradicionalmente não eram considerados como trabalhadores na década de 1930?

\section{Lenita e O País do Carnaval: dois ensaios para o realismo}

A novela Lenita ${ }^{3}$ foi escrita por Carneiro, Amado e Oswaldo Dias das Costa em 192954, em forma de fascículos em $O$ Jornal. $\mathrm{Na}$ introdução da obra, seus autores disseram que a intenção era escrever um texto sem as "algemas clássicas nem pretend[iam] tomar passagem nos hiper-aviões futuristas"55. No website "Jorge Amado", da editora Companhia das Letras, última a editar a obra completa do escritor, consta um texto de apresentação biográfica, no qual afirma que o autor assinou a novela com o pseudônimo de "Y. Karl'56.

O jornal Diário de Notícias, no dia 20 de novembro de 1931, fez menção ao texto dos rebeldes na seção "Livros Novos" como um dos novos lançamentos ${ }^{57}$. Já o Diário da Manbã, do Espírito Santo, no

47 SANTOS, El realismo socialista en tierras tupiniquines;

48 SANTOS, Hoz, martillo, resistencia, sudor y pueblo en el brasileño Jorge Amado, p. 42.

${ }^{49}$ MORAES, Denis apud SANTOS, El realismo socialista en tierras tupiniquines.

50 Cf. SANTANA, op. cit.; SANTOS, El realismo socialista en tierras tupiniquines.

51 Sobre este aspecto, ver análise interessante: SANTANA, op. cit., p. 145-204.

52 SANTOS, Hoz, martillo, resistencia, sudor y pueblo en el brasileño Jorge Amado, p. 42-43; SANTOS, El realismo socialista en tierras tupiniquines.

53 Segundo os autores Maria das Graças Nunes Cantalino e Ricardo Henrique Resende de Andrade, tem uma edição rara do romance no Centro de Documentação e Informação Cultural sobre a Babia (Sedic-Ba) da Fundação Clemente Mariani (FCM). CANTALINO, Maria das Graças Nunes; ANDRADE, Ricardo Henrique Resende de. Lenita: um livro não amado. Entrelaçando: Revista Eletrônica de Culturas e Educação, Amargosa, v. 1, n. 1, p.111, out. 2010.

54 OLIVEIRA, Olivia Fernandes de. Notas sobre algumas páginas mais ou menos modernas. O 'Modernismo' na Bahia através das Revistas. RUA. Revista de Arquitetura e Urbanismo, Salvador, v. 7, p. 14, 1999.

55 ROSSI, Luiz Gustavo Freitas. O intelectual "feiticeiro": Édison Carneiro e o campo de estudos das relações raciais no Brasil. 2011. p. 123. Tese (Doutorado em Antropologia) - Universidade Estadual de Campinas, Campinas, 2011.

56 Consultar site organizado pela Companhia das Letras em: http://www.jorgeamado.com.br/vida.php3. Acesso em: 25 de nov. 2016.

${ }^{57}$ Diário de Notícias, Rio de Janeiro, p. 4, 20 nov. 1931. 
dia 21 de janeiro de 1932, lançou a seguinte nota: “- Uma interessante novela, contendo a narração entusiástica de três brilhantes espíritos. [...] 'Lenita' é um trabalho original e bem feito" 58 . Num tom humorado, Amado comentou que Lenita foi a pior novela do mundo publicada pelo editor A. Coelho Branco Filho. Os direitos autorais foram pagos em forma de livro. E acrescentou que o editor certamente não leu os originais ${ }^{59}$. Para os autores Maria das Graças Nunes Cantalino e Ricardo Henrique Resende de Andrade, o enredo gira em torno de um cenário caótico, onde os autores disputavam pelo controle do enredo da história. Nesse sentido, as

personagens da novela são tipos pervertidos como a magra e sensual Lenita; Alberto Neves e sua amante intempestiva Saxe; os noctívagos Farias, Gomes e Guedes; José Menéndez, o arquiteto vagabundo e drogado; Costa Vieira, poeta lírico, apaixonado pela "sensual" Ester-Alda, descrita como uma virgem histérica e lasciva. Todos imersos num ambiente de luxúria e luxo.60

Ainda acrescentou Amado que:

aconteceu que Édison no segundo capítulo criou uma mulherzinha terrível de magra e de feia para heroína. Eu, que neste tempo vivia sob a influencia de uma pequena lírica sentimental, matei a prostituta no terceiro capítulo para moralizar o livro. Édison se danou e então fêz da alma da mulher a heroína do livro. Cada qual queria atrapalhar o outro e acabou saindo um novela horrorosa. ${ }^{6}$

Amado, no dia 6 de dezembro de 1934, de forma humorada, colocou em sua pequena biografia divulgada pela Gazeta de Notícias, do Rio de Janeiro, que tinha curiosidade em saber quem teria comprado aquele livro, que inclusive considerava como "um dos piores livros que já foram publicados no Brasil"'62. O escritor e ensaísta José Joaquim de Campos da Costa de Medeiros e Albuquerque (Medeiros e Albuquerque), escreveu num artigo publicado pelo periódico Vida Literária (1932) que o romance "é uma pura abominação"63.

Gostando ou não de Lenita, o escritor num tom de justificativa asseverou que foi "a cerveja do Bar Brunswick responsável por uma miserável novela" que escreveu junto com seus companheiros ${ }^{64}$. Amado relegou Lenita ao esquecimento, na medida em que não quis colocá-la numa posição de destaque dentre os outros romances que escreveu em 1930. Segundo a Companbia das Letras, o escritor chegou a comentar que é "uma coisa de criança. Nós éramos muito meninos quando fizemos Lenita" 65.

58 Diário da Manhã, Espírito Santo, p. 1, 21 jan. 1932.

59 TÁTI, op. cit., p. 20-21.

${ }^{60}$ CANTALINO; ANDRADE, op. cit., p. 113.

${ }_{61}$ AMADO, Jorge apud Ibidem, p. 20-21.

62 Ibidem, p. 20.

63 ALBUQUERQUE, José Joaquim de Campos da Costa de Medeiros e apud AMADO, Jorge Amado: 30 anos de literatura, p. 57; Cf. CANTALINO; ANDRADE, op. cit., p. 112.

64 AMADO, Jorge apud PALAMARTCHUK, Ana Paula. Ser intelectual comunista: escritores brasileiros e o comunismo (1920-1945). 1997. p. 110-111. Dissertação (Mestrado em História) - Universidade Estadual de Campinas, Campinas, 1997 ; Cf. CANTALINO; ANDRADE, op. cit., p. 112; GOLDSTEIN, Ilana Seltzer. O Brasil Best Seller de Jorge Amado: literatura e identidade nacional. São Paulo: Editora SENAC, 2003. p. 123.

65 Consultar site organizado pela Companhia das Letras em: http://www.jorgeamado.com.br/vida.php3. Acesso em: 25 de nov. 2016. Também consta no site da Fundação Casa de Jorge Amado, que "Neste livro consta a seguinte nota: Esta novela foi publicada, em folhetim, com o título primitivo de 'El-Rei...', n' 'O Jornal', da Baía, em Abril de 1930, e assinada com os pseudônimos GLAUTER DUVAL, JUAN PABLO e Y. KARL, respectivamente, OSWALDO DIAS DA COSTA, EDISON DE SOUZA CARNEIRO e JORGE AMADO". Disponível em: http://acervo.jorgeamado.org.br/item/310071056081. Acesso em: 25 de nov. 2016. 
O Sr. Jorge Amado tinha para com todos nós uma dívida pesada: as horas gastas com a novela com que estreou há alguns meses em colaboração com os dois autores: "Lenita".

O fato era mesmo curioso. Três rapazes, evidentemente inteligentes e capazes, tinham reunido os seus esforços para dar vida a uma história que lhes parecia de interêsse. O resultado era a novela mais falsa e vazia que é possível conceber. Apesar de todo o esfôrço ser nesse sentido, nem originalidade tinham conseguido.

Quem já conhece o sr. Jorge Amado facilmente poderia fazer crédito - e tanto a êle como aos dois outros novelistas. Foi o meu caso. Do srs. Edison Carneiro e Dias da Costa ainda espero prova positiva - de que não duvido aliás. ${ }^{66}$

O fragmento foi retirado de um artigo publicado pelo escritor, crítico literário e ensaísta Octávio ${ }^{67}$ de Faria que colaborou com a revista Literatura dirigida por Augusto Frederico Schmidt, futuro editor de $O$ país do carnaval. Não podemos deixar de lembrar que foi Octávio de Faria o responsável pela apresentação de Amado ao editor ${ }^{68}$. Quando Amado se transferiu para o Rio de Janeiro com o intuito de terminar o ensino secundário ingressou na Faculdade de Direito do Rio de Janeiro, onde integrou o grupo de seu primo Gilberto Amado, do qual Octávio de Faria fazia parte ${ }^{69}$.

$\mathrm{O}$ fato de Amado fazer parte da rede de sociabilidade do ensaísta acabou ajudando no encaminhamento da crítica e amortização de comentários que poderiam soar como ácidos. Nota-se, em sua fala, apesar da crítica demolidora feita a Lenita, uma consideração quanto ao talento dos escritores rebeldes. $\mathrm{O}$ autor não põe em cheque a inteligência dos jovens escritores e reiterou que o livro editado por Augusto Frederico Schmidt é a retratação do jovem escritor baiano frente à comunidade intelectual do país.

Lenita é uma das primeiras tentativas de escrita dos rebeldes. Fora um ensaio para $O$ país do carnaval - primeiro romance amadiano consagrado pelos críticos -, já que "conseguiu uma certa estima literária" sendo, por isso, o menos atacado ${ }^{70}$. Notamos que nele há a influência da vivência do escritor quando ainda era da Academia dos Rebeldes (AR) ${ }^{71}$.

Não estamos em total acordo com Palamartchuk quanto ao processo de escrita de $O$ país do carnaval. Para a historiadora, o livro foi escrito no final de 1930 quando Amado, ainda estudante, tentava terminar o "ginásio" no Rio de Janeiro ${ }^{72}$. Baseados em entrevista cedida por Amado à Raillard, como na tese de Júlia Monnerat Barbosa, sustentamos que apenas os dois últimos capítulos foram terminados no Rio de Janeiro. Além disso, não encontramos no comentário de Palamartchuk nenhum tipo de fonte ou bibliografia que sustente sua afirmação ${ }^{73}$.

No primeiro romance amadiano, fica clara a intenção de representar na ficção os problemas que sua geração estava enfrentando na vida real, como a incerteza de qual caminho seguir. Amado transporia não apenas as suas dúvidas perante os caminhos incertos da vida, como enveredaria por uma tentativa de representação do cenário intelectual baiano da década de 1930, tendo como base sua experiência na AR, pois nas palavras do próprio Amado, suas melhores recordações "são as do tempo

${ }^{66}$ FARIA, Octávio apud apud AMADO, Jorge Amado: 30 anos de literatura, p. 60 e 65.

${ }^{67}$ Estamos mantendo a forma como o nome aparece no artigo do autor.

68 AMADO; GOMES, op. cit., p. 15-16.

${ }^{69}$ RAILLARD, op. cit., p. 52-53.

70 AMADO; GOMES, op. cit., p. 15.

71 SANTANA, op. cit., p. 72-92.

72 PALAMARTCHUK, Ana Paula. Os novos bárbaros: escritores e comunismo no Brasil (1928-1948). 2003. p. 91. Tese (Doutorado em História) - Universidade Estadual de Campinas, Campinas, 2003.

73 RAILLARD, op. cit., p. 45 e 51; BARBOSA, Júlia Monnerat. Militância política e produção literária no Brasil (dos anos 30 aos anos 50): as trajetórias de Graciliano Ramos e Jorge Amado e o PCB. 2010. p. 112. Tese (Doutorado em História) - Universidade Federal Fluminense, Niterói, 2010. 
em que com Pinheiro Viegas (hoje cego e pobre) e um grupo de amigos fazíamos na Boa Terra uma literatura danada" 74 .

O escritor baiano teve a sorte de contar com o interesse de Octávio de Faria pelos originais de O país do carnaval. Já dissemos que foi através de Faria que os originais do romance chegaram às mãos do Augusto Frederico Schmidt, que tinha uma editora e livraria ${ }^{75}$. Este editor lançou obras de autores como Rachel de Queiroz, Lucio Fontes, José Geraldo Lima, Armando Fontes, Marques Rabelo, Graciliano Ramos e outros que se consagrariam como a Geraşão de $1930^{76}$.

Havia um homem muito ligado ao Schmidt, chamado de Tristão da Cunha. Ele tinha traduzido Shakespeare, tinha escrito um livro de viagem sobre a Islândia, era muito respeitado no mundo literário. Não confundir com o outro Tristão da Cunha, aquele que foi deputado... não sei se eram parentes ou não. Um dia ele foi ver o Schmidt, o Schmidt não estava, ele sentou à frente da mesa, pegou os originais do meu livro na gaveta e começou a ler.

Quando o Schmidt chegou, eles conversaram o que tinham que conversar e depois me perguntou quem era o autor daqueles originais. O Schmidt respondeu que eu era primo do Gilberto Amado, os originais tinham sido levados pelo Otávio de Faria etc. Aí o Tristão da Cunha pediu emprestado e levou. ${ }^{77}$

Depois de alguns dias Tristão da Cunha escreveu para Jorge Amado o parabenizando pelo trabalho. Fez o mesmo para Augusto Frederico Schmidt recomendando a publicação imediata do livro, que foi editado em setembro de 1931, sendo bem recebido entre os intelectuais ${ }^{78}$.

O romance está conectado aos problemas que afetaram a Geração de 30, ou, como diria Táti, foi escrito por um homem "compromissado com os problemas do tempo". Diria o próprio Amado que este "livro é um grito. Quase um pedido de socorro. É toda uma geração insatisfeita, que procura a sua felicidade. - Nós já começamos a luta contra dúvida"79. Na leitura de Duarte, o romance acaba trazendo algumas questões caras à geração do autor, como: "O que somos?", "que país é este?", "para onde vamos?" 80 . Ainda na interpretação de Duarte, o primeiro livro amadiano segue a mesma pegada regionalista (do Modernismo) de O Quinze (Rachel de Queiroz) e A Bagaceira (José Américo de Almeida) sendo, ao mesmo tempo, uma espécie de cruzamento da estética do regionalismo recifense (liderado por Gilberto Freyre e José Lins do Rego) e do movimento modernista (dos artistas e escritores cariocas e paulistas da Semana de 22) $)^{81}$.

Não concordamos totalmente com a interpretação de Duarte sobre a estética de $O$ país do carnaval. Estamos de acordo que Amado tenha se inserido dentro desse movimento regionalista (marcado pelo regionalismo tradicionalista de Freyre e Rego e o tradicionismo dinâmico de Carlos Chiacchio) que começa a surgir no final da década de 1920 entre as cidades de Salvador e Recife. Esse movimento buscou uma espécie de universalidade dos problemas enfrentados pela região Nordeste como a fome, a miséria, a dor, assim como a valorização das culturas afro-brasileiras e indígenas ${ }^{82}$.

\footnotetext{
74 RAILLARD, op. cit.

75 AMADO; GOMES, op. cit., p. 15-16.

76 BARBOSA, op. cit., p. 122-123.

77 AMADO; GOMES, op. cit., p. 16. A pesquisadora Ilana Seltzer Goldstein faz um breve comentário sobre a participação de Amado no grupo católico da Faculdade de Direito do Rio de Janeiro, onde seu primo Gilberto Amado era membro. GOLDSTEIN, op. cit., p. 124.

78 BARBOSA, op. cit., p. 112.

79 TÁTI, op. cit., p. 24-26.

${ }^{80}$ DUARTE, op. cit., p. 50.

81 Ibidem, p. 46-47

82 Ver debate em: SANTANA, op. cit., p. 55-72. Além das referências consultadas pelo pesquisador Geferson Santana, consultar: NASCIMENTO, Gabriel Renato do. Carlos Chiacchio: um projeto modernista na Bahia (1928-1947). 2016.145 f. Dissertação (Mestrado em História) - Universidade Federal de São Paulo, Guarulhos, 2016.
} 
Por outro lado, não concordamos com a associação simplista do primeiro romance amadiano com o modernismo, considerando que o próprio Jorge Amado desautorizou qualquer associação de seus romances ou da agremiação AR ao movimento modernista paulista-carioca. Nas palavras do próprio autor:

Não nos pretendíamos modernistas, mas sim modernos: lutávamos por uma literatura brasileira que, sendo brasileira, tivesse um caráter universal; uma literatura inserida no momento histórico em que vivíamos e que se inspirava em nossa realidade, a fim de transforma-la. ${ }^{83}$

Nesse sentido, acreditamos que é necessário uma análise mais profunda da fala de Amado, quando afirmou que: "Não nos pretendíamos modernistas, mas sim modernos". Ou seja, mesmo que o autor tenha reconhecido que o "modernismo destruiu os velhos padrões liberais do país" 84 , acabou afirmando que pouco se esforçaram os modernistas para "renovar". Também disse Amado que os modernistas destruíram muitas coisas, mas nada construíram ${ }^{85}$. Parece que a memória dele em torno da "improdutividade" do modernismo tem ligação com a afirmação que o editor da primeira edição de $O$ pais do carnaval, Augusto Frederico Schmidt, fez sobre o modernismo, porque o "movimento modernista iniciado por Graça Aranha, e que Mario de Andrade e outros mais sistematizaram, foi o movimento de afirmação do espírito. Mas o movimento morreu e não nos diz hoje mais nada" 86 . Acreditamos que é necessária uma análise mais consistente para pensar na relação de $O$ país do carnaval com o modernismo.

Mas, ainda analisando para além das questões estéticas, o escritor Carneiro ponderou que o primeiro livro "não é romance, tendo apenas o merito, muito grande, mas único, de haver fixado um 'momento' da angustia intellectual da juventude" 87 . Augusto Frederico Schmidt teria uma impressão um pouco parecida, avaliando na Carta-Prefácio do romance que é "antes de tudo um forte documento do que somos hoje, nós mocidade brasileira, mocidade sem solução, fechada em si mesma, perdida numa terra que nos dá a todo momento a impressão de que sobramos" 88 .

Seu livro acordou em mim velhas revoltas sufocadas e recalcadas contra a vida e a terra em que vivemos. Paulo Rigger, seu personagem não é cerebral, não é um filho do ocidental saturado e exasperado de cultura, é apenas um pobre moço brasileiro como eu, como você, como todos nós. Nós estamos vivendo o momento do tédio. As gerações se sucedem vertiginosamente. E vêm árdegas, querendo realizar alguma coisa, manter acesa a lâmpada do espírito. Mas em pouco tempo suficiente para se realizar. E não deixamos nem sequer um traço da nossa passagem. Eu, pouco mais velho que você, já me sinto muito distante de tudo, num desinteresse sempre crescente, pelo que alimentou o meu gosto pela vida. Não temos frescura, nem nos podemos repousar nos bons silêncios. Viemos para gritar que existimos, diante de uma nação adormecida e indiferente. Cansamos, porém logo. E assistimos com melancolia à vinda dos que ainda acreditam que é possível gritar, que é útil gritar. ${ }^{89}$

Schmidt aproveita o prefácio para fazer um desabafo marcado por um pessimismo dosado. Ao dizer que os problemas vividos pela personagem Paulo Rigger representam aquilo que eles estão

83 OLIVEIRA, op. cit., p. 14. Ver também análise em: GOLDSTEIN, op. cit., p. 129-130.

84 TÁTI, op. cit., p. 90.

85 Ibidem, p. 91-92.

86 SCHMIDT, Augusto Frederico apud AMADO, Jorge Amado: 30 anos de literatura, p. 57. Ainda sobre uma análise sobre este aspecto ver SANTANA, op. cit., p. 88-91.

87 CARNEIRO, Edison. Uma toada triste vem do mar. O Jornal, Rio de Janeiro, p. 3, 24 nov. 1935.

88 SCHMIDT, Augusto Frederico apud AMADO, Jorge Amado: 30 anos de literatura, p. 55. Não podemos esquecer que a análise de Goldstein corrobora a nossa: Cf. SANTANA, op. cit., p. 101-103; GOLDSTEIN, op. cit., p. 123-124.

${ }^{89}$ Idem. 
passando, o crítico acabou aproximando gerações diferentes, a dele e do autor. Do mesmo modo, notase um cansaço que não podemos ver, mas sentimos por meio do discurso. É como se não apenas o tempo cansasse, como o cenário de mesmice que viviam os "homens de letras", pois ainda se vivia numa "nação adormecida e indiferente". Em contrapartida, o autor demonstrou ânimo frente ao surgimento de novos intelectuais dispostos a gritar, e não foi por acaso que ele se tornou um dos editores que mais lançou autores promissores.

Dentre os vários elogios, não faltou fôlego para as críticas. Esclareceu Schmidt, que o livro ainda era "balbuciante" por se tratar de um escritor estreante. "Os homens que se movem dentro dela são homens e não personagens de símbolos. $O$ que você quis dizer e por vêzes não o conseguiu inteiramente, nós o podemos saber por você próprio e pela nossa experiência" 90 . Acrescentou que todos os romances brasileiros são ricos em cenários belos e verdadeiros, e a ausência deles no romance de Amado é um de seus defeitos e qualidades ${ }^{91}$. Mas, colocou Octávio de Faria em artigo já citado, que os defeitos são superados pelas qualidades ${ }^{92}$.

Medeiros e Albuquerque comentando o romance afirmou que quem olha para a folha de rosto e lê o prefácio do livro não tem nenhuma vontade de conhecê-lo. Com isso, perde o leitor a oportunidade de ter contato com um excelente livro, que é "Bom, bem feito, vivo, tem, é certo, um evidente excesso de diálogos sobre narrações e descrições, excesso que podia ser evitado, mas não lhe prejudica o encanto" 93 .

Edison Carneiro esclareceu que “"O Paiz do Carnaval' demarcou o inicio de uma evolução que prenunciava grandes triumphos no romance social" 94 . Nelson Werneck Sodré ponderou que o romance tem inspiração nas vivências do escritor quando era um rebelde ${ }^{95}$, ideia que seria confirmada por Amado na entrevista dada a Raillard ${ }^{96}$. Segundo Silva, o escrito literário retrata o campo intelectual de finais dos 1920 e inícios de 1930. Ou, como afirmou o rebelde Sosígenes, é "um espelho cruel" daquela geração atormentada pelas incertezas ${ }^{97}$. Esse mesmo sentimento do autor é compartilhado por Duarte, quando afirma que "prevalece a negação do status quo. Nenhum dos personagens encontra o 'verdadeiro sentido da existência', todos se frustram ou se iludem"98. Ainda para Sosígenes, trata-se de um romance que: "Diz respeito duplamente à vida intelectual soteropolitana: é produto do ambiente literário local e possui como tema a natureza da vida intelectual, isto é, suas limitações, impasses, dúvidas e perspectivas". ${ }^{99}$

$\mathrm{Na}$ leitura do jornalista e escritor Heitor Marçal, o romance é uma biografia de sua geração, porque "Lendo-o a gente só repara uma coisa: presença. Atualidade. Com a soma alta de inquietação. E quem dirá que essa agitação toda não é uma herança do passado?" ${ }^{100}$. Acrescentou que tanto nesse quanto nos romances de Rachel de Queiroz e demais escritores daquela geração, não se tem preocupação com a forma, "não há lugar para a frase derramada e piegas que faz a delícia da gente leitureira"101.

\footnotetext{
90 Idem.

${ }^{91}$ Ibidem, p. 56.

92 FARIA apud AMADO, Jorge Amado: 30 anos de literatura, p. 61.

93 ALBUQUERQUE apud AMADO, Jorge Amado: 30 anos de literatura, p. 58.

94 CARNEIRO, Edison. Notas sobre "Suor". O Jornal, Rio de Janeiro, p. 3, 21 out. 1934.

95 SODRÉ, Nelson Werneck. Pinheiro Viegas. Correio Paulistano, São Paulo, p. 13, 28 mai. 1939.

${ }^{96}$ RAILLARD, op. cit., p. 46.

${ }_{97}$ Costa, Sosígenes apud AMADO, Jorge Amado: 30 anos de literatura, p. 59-60.

98 DUARTE, op. cit., p. 52.

99 SILVA, op. cit., p. 108-109.

100 MARÇAL, Heitor apud AMADO, Jorge Amado: 30 anos de literatura, p. 65.

${ }^{101} \mathrm{Idem}$
} 


\section{Cacau, Suor, Jubiabá e Mar morto: o romance proletário?}

Se o primeiro romance foi uma tentativa, nem sempre exitosa, de representação de uma geração e seus problemas, em Cacau (1933) Amado apresentou um caminho. Segundo Barbosa, é nesse romance que o escritor baiano põe à vista sua aproximação com as orientações do PCB ${ }^{102}$. A autora não está equivocada, porque fora com esse romance que Amado tentou representar o cenário de exploração dos homens que trabalharam nas plantações de cacau dos grandes coronéis da cidade de Ilhéus, no Sul da Bahia. Outras questões também são representadas como a condição de miséria em que viviam os trabalhadores como, por exemplo, as prostitutas, às quais se condicionou a chamar de "operárias do sexo". Eduardo de Assis Duarte, afirma que Cacau é a demonstração de que o caminho do escritor baiano seguiu em direção à esquerda, pois o interesse em representar os latifúndios e suas mazelas socioeconômicas tinha uma relação direta com as diretrizes do $\mathrm{PCB}^{103}$.

Segundo o médico e escritor chileno Juan Marín, num artigo que escreveu para a revista El Mercurio da cidade de Santiago (Chile), o romance é "dramatico como la verdad y como la vida mismo" 104 . Segundo Duarte, o romance tinha a função de representar o sofrimento dos trabalhadores das fazendas de cacau, especialmente as condições de subsistência, como moradias precárias, alimentação de péssima qualidade e exploração da força de trabalho ${ }^{105}$.

Marín também lembrou que o livro causou tanta repercussão e polêmica que acabou sendo apreendido pela polícia. Palamartchuk reporta o ocorrido:

A publicação de Cacau teve grande repercussão entre os críticos literários e, também, entre a polícia carioca que o apreendeu, mas por intervenção de Oswaldo Aranha (então, Ministro do Exterior) foi liberado 24 horas depois. Talvez até por causa da apreensão é que o livro fez sucesso entre o público: a primeira edição, maio de 1933, contou com 2000 exemplares e se esgotou em um mês, tendo a segunda edição, julho-agosto de 1933, 3000 exemplares. ${ }^{106}$

Acreditamos que Palamartchuk tem toda razão ao afirmar que a apreensão dos exemplares tenha gerado impacto entre os escritores, mas $O$ país do carnaval, apesar das críticas, conquistou os críticos da época. Com Cacau não foi diferente. Até mesmo o integralista sergipano Omer Mont'Alegre elogiou o romance no jornal Estado de Sergipe e estimulou seu autor dizendo que ele "tirou a roupa da verdade. Arrancou-lhe a dentadura. O ôlho de vidro. A cabeleira (...) Você há de ser combatido por causa de seu livro. Não esmoreça. Faça outro"107.

Explicou Marín que, com Cacau, Amado se tornou "uno de los cuatro o cinco más grandes novelistas de America em la hora actual: está junto a Gallegos, Rivera, Azuela y Icasa"108. No cenário nacional, o jornalista Odilo Costa Filho incluiu o romance junto com Menino do engenho de José Lins do Rego e João Miguel de Rachel de Queiroz no rol das grandes obras brasileiras, tendo em vista que "este Jorge Amado fez coisa tão pouco literária que qualquer outro não faria”109.

\footnotetext{
102 BARBOSA, op. cit., p. 134 e 136. Interessante notar que alguns autores como Goldstein não deixam clara a relação de Amado com o referido partido. GOLDSTEIN, op. cit., p. 135.

103 DUARTE, op. cit., p. 56-57.

104 MARÍN, Juan apud AMADO, Jorge Amado: 30 anos de literatura, p. 70.

105 DUARTE, op. cit., p. 63. Para análise do romance, consultar: SANTANA, op. cit., p. 170-182; SANTOS, El realismo socialista en tierras tupiniquines. Ainda consultar as referências usadas por Santana.

106 PALAMARTCHUK, Ser intelectual comunista: escritores brasileiros e o comunismo (1920-1945), p. 117. Cf. DUARTE, op. cit., p. 74.

107 MONT'ALEGRE, Omer apud AMADO, Jorge Amado: 30 anos de literatura, p. 78.

108 MARÍN apud Ibidem, p. 70.

${ }^{109}$ COSTA FILHO, Odilo apud AMADO, Jorge Amado: 30 anos de literatura, p. 77.
} 
Suor (1934) teve um caminho diferente dos anteriores. Seus rascunhos começaram em 1928 quando Amado residia num casarão no Pelourinho. Nele, o autor continuou sua busca pela representação das condições sociais e econômicas em que viviam os trabalhadores baianos. O cenário principal é um cortiço fétido na ladeira do Pelourinho, onde moravam estivadores, costureiras, prostitutas, operários e tantos outros sujeitos esquecidos pelo governo, mas lembrados pelo locador nos dias de pagamento dos alugueis ${ }^{110}$. Para Betina Ribeiro Rodrigues da Cunha, as personagens do enredo são tomadas como "sujeitos-objetos" ou "sujeitos-impressões" para representar a cenário de exclusão e sofrimento, residindo aí o caráter engajado do romance que se quer afirmar como proletário ${ }^{111}$. Diz ainda a autora que

As narrativas são uma prosa fragmentada, que se assemelha a uma sucessão de temas e contos reunidos por um único endereço, Ladeira do Pelourinho, $\mathrm{n}^{\circ}$ 68, sobrado com quartos subdivididos até o máximo da promiscuidade, opressivo e desumano respeito ao homem. Este sobrado, objeto simbólico de um cotidiano de miséria, de lixo e de suores, se mistura, fazendo valer - em uma voz polifônica que resgata, dentre tantos tipos excluídos em uma subcondição humana - uma consciência lírica a denunciar a exploração do outro e o caminho revolucionário. ${ }^{112}$

Todo esse cenário caótico construído por Amado, representa os problemas enfrentados pelas classes mais pobres soteropolitanas ${ }^{113}$. Segundo Santos, a intenção do autor é "describir la labor diaria de los oprimidos de este contexto social. Ahora bien, en esta obra describe la vida cotidiana de carácter pobre y subyugado del lumpenproletariado en Salvador"114. Por outro lado, na leitura de Cunha, esses sujeitos oprimidos podem ser considerados como "beróis anônimos" 115 , mas tal leitura confronta-se com a de Duarte, que defende a ideia de uma ausência do herói na narrativa que, outrossim, dá espaço para personagens que são descritas de maneira positiva, garantindo assim a cidadania desses sujeitospersonagens ${ }^{116}$.

O Sr. Jorge Amado é um dêsses escritores inimigos da convenção e da metáfora, desabusados, observadores atentos. Conheceu, há alguns anos, um casarão de três andares na ladeira do pelourinho, Bahia, e resolveu apresentar-nos os hóspedes que lá encontrou - vagabundos, ladrões, meretrizes, operários, crianças viciadas, agitadores, sêres que se injuriavam em diversas línguas: árabes, judeus, italianos, espanhóis, pretos, retirantes do Ceará, etc. Até bichos. Essa fauna heterogênea não se mostra por atacado na obra do romancista baiano: forma uma cadeira que principia no violinista que percorreu a França, a Alemanha, outros países, e acaba no rato que dorme junto à esteira de um mendigo. ${ }^{117}$

A fala do escritor Graciliano Ramos é significativa. Ele acreditou que o movimento feito por Amado representou um esforço dos escritores de sua geração em querer entender os lugares e os sujeitos que podemos considerar como periféricos, como o engenho, a fábrica e o subúrbio, sem medo de "falar errado como tôda gente, sem dicionário, sem gramática, sem manual de retórica. Ouviram

110 Consultar trabalho de: CUNHA, Betina Ribeiro Rodrigues da. Poeticas da negritude e da exclusão em Jorge Amado. Izquierdas, Santiago de Chile, n. 32, p. 172-183, mar. 2017. Ver réplica do mesmo artigo em: CUNHA, Betina Ribeiro Rodrigues da. Suor ou Ladeira do Pelourinho, $\mathrm{n}^{\circ} 68$ : uma poética da exclusão. Amerika, n. 10, 2014. Disponível em: https://journals.openedition.org/amerika/4830. Acesso em: 23 jul. 2018.

111 Ibidem, p. 174.

112 Ibidem, p. 176.

113 SANTANA, op. cit.

114 SANTOS, El realismo socialista en tierras tupiniquines

115 CUNHA, op. cit., p. 177.

116 DUARTE, op. cit., p. 76, 83 e 84.

117 RAMOS, Graciliano apud AMADO, Jorge Amado: 30 anos de literatura, p. 84. 
gritos, pragas, palavrões, e meteram tudo nos livros que escreveram"118. Graciliano Ramos acrescentou que esses escritores poderiam ter trocado os gritos por suspiros e os palavrões por orações, mas resolverem "pôr os pontos nos ii".

O que liga os anéis da cadeia não é o trabalho, como o título do livro, Suor, poderia fazer-nos supor: é miséria, miséria completa, nojenta, esmolambada, sem nenhuma espécie de amparo. Todos os habitantes do prédio vivem na indigência ou aproximam-se dela. Sente-se, de fato, o cheiro de suor, pois logo no começo, surgem à porta alguns trabalhadores do cais do pôrto. Esses trabalhadores, porém, à exceção do preto Henrique, mexem-se pouco. Sentimos bem é um fedor de muitas coisas misturadas: lama, pus, cachaça, urina, roupa suja, sêmen - uma grande imundícia apanhada com minudências excessivas. ${ }^{119}$

Oswaldo Dias da Costa, ex-membro da AR, teve uma percepção muito parecida sobre o enredo, e apontou que com o terceiro livro Amado apresentou para seus leitores um "produto novo". Conforme Dias da Costa, o autor demonstrava estar seguro sobre qual caminho seguir, esforçando-se para dar o melhor e com "a maior honestidade, na árdua caminhada que se impôs, combatendo pela idéia que sinceramente adotou e que julga, com toda bôa fé, ser a única capaz de resolver problemas que se lhe afiguram angustiosas"120. Jubiabá (1935) acabou reforçando o empenho de seu autor em seguir um caminho, uma direção no "fazer literário" sob a orientação do PCB. Assim descreve Barbosa a personagem principal do romance:

Balduíno, órfão criado pela tia no morro do Capa Nego, em Salvador, em sua primeira infância, teve existência pobre mas conhecia uma estrutura familiar estável com a tia. Sua vida muda quando sua tia é internada em um hospício e ele é acolhido como criado na casa de um rico comendador, na Travessa Zumbi dos Palmares, onde permanece até os 15 anos. Depois vira mendigo no Pelourinho, malandro errante pelas ruas da cidade na idade adulta, plantador de tabaco, lutador de boxe e compositor de modinhas, até conhecer a redenção final como líder proletário. Seu sonho, desde criança, era ter sua vida cantada em um ABC, como os que louvavam os grandes cangaceiros do sertão. ${ }^{121}$

Temos aí uma excelente apresentação do enredo feita pela autora, e quem leu acrescentaria apenas as descrições sobre as festas nos terreiros de candomblé, ou mesmo as belas narrativas em torno da Baía de Todos os Santos.

Em carta a Amado, Rachel de Queiroz afirmou a grandiosidade do quarto romance entregue aos leitores. Era o exemplar que tanto esperava, superando a expectativa da escritora:

Grande, grande livro, seu Jorge. Cheio duma estupenda poesia, duma poesia de sôpro largo e formidável. Poesia que você não revelara ainda em seus livros anteriores, senão em traços ligeiros. Figuras que aparecem que vêm cercados de luz, como aquela Maria da barcaça, aquela que canta de cabelos soltos animando o marinheiro. E o Gordo, com todo o seu trágico burlesco e terníssimo...122

É inegável que Jorge Amado teve a total aprovação dos amigos vinculados ou não ao PCB, como José Lins do Rego, Rachel de Queiroz, Edison Carneiro, Josué de Castro, e tantos outros críticos literários e escritores não vinculados ao círculo de sociabilidade do baiano. Não encontramos nenhum

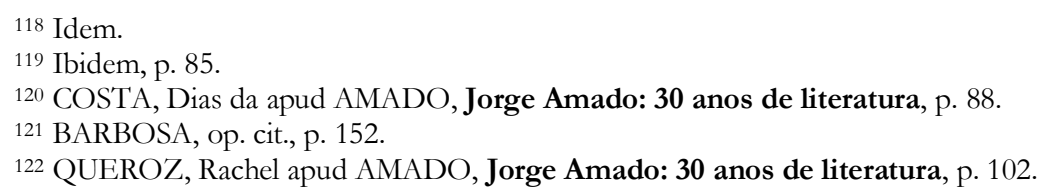


tipo de crítica que levantasse muitos problemas do romance, com exceção de José Lins do Rego que exigiu do autor ser "mais realista" 123.

Nos chamou a atenção o comentário de Monteiro Lobato, que afirmou ser Mar morto (1936) o auge de seu criador, deixando Jubiabá apenas na posição de mais um excelente livro escrito ${ }^{124}$. O enredo traz representações em torno da vida dos moradores dos portos de Salvador, mostrando os códigos de conduta, vida dos mestres de saveiro e pescadores, prostituição, bares e as condições de miséria em que viviam em suas casas pequenas e insalubres. No texto publicado na $3^{\circ}$ edição da obra, disse Lobato:

Jorge Amado: Recebi o "Mar Morto" que me ofereceu. Li-o em três sentadas, com a mesma emoção trágica que seus livros sempre despertam. Em novembro do ano passado estive por várias vêzes naqueles cais, perto da igreja da Conceição da Praia, vendo os saveiros atracados e os que vinham vindo de velas abertas - e pensei em você. "Qualquer dia o Jorge Amado presta atenção e pinta os dramas que devem existir aquil". Adivinhei.

Seus livros da Bahia revelam-me mais que um escritor, que um romance, que um artista. Revelam-me uma força da natureza, uma espécie de harpa eólia que ressoa a passagem dos ventos dos dramas da miséria. Daí a especialíssima impressão que me causam - única, inconfundível e trágica. Tragédia no sentido grego da palavra. Na planura da literatura brasileira Jorge Amado vai ficar como um bloco súbito de montanha híspido, cheia de alcantis, de cavernas, de precipícios, de massas brutas da natureza. ${ }^{125}$

Lobato acreditou que o quinto romance superou disparadamente o anterior. No mesmo artigo, assegurou que o livro demonstrou as potencialidades de um autor que não tem uma forma definida para escrever, e por isso são livros de dar dor de cabeça em "acadêmicos, aos brochas, aos seguidores de regras de arte, aos onanistas da forma" 126 .

Raul Bopp, no artigo publicado pela revista Diretrizes, em 1939, corroborou as impressões de Rachel Queiroz e Gilberto Amado ${ }^{127}$ sobre a essência poética do romance, evidenciando o caráter "fabuloso" do enredo com negros "de olhos esticados pra África, pras terras de Aiocá128. Os mestres de saveiros tão trabalhando, tão dançando, tão cantando" 129 . Concluiu o poeta afirmando que ninguém mais seguraria o homem de Cacau, que "disparou pelo mar adentro, foi ver Iemanjá. Ninguém mais pega êle não"130.

Aydano do Couto Ferraz anotou que com Capitães de areia (1937), havia se fechado um ciclo que Amado denominou de "Romances da Bahia". O sexto romance

é um livro que revela ao Brasil aspectos inteiramente desconhecidos da vida das crianças abandonadas na cidade do Salvador, crianças que roubam nas feiras, adoram feitos de cangaceiros, amam à luz das estrelas. Infância abandonada do meio da qual saem, indiferentemente, bandoleiros ou cantadores de abc. ${ }^{131}$

Podemos dizer que muitos dos críticos literários, escritores e jornalistas que escreveram sobre a obra de Amado nos jornais e revistas da década 1930 eram de vários estados do país, sendo a maioria

123 REGO, José Lins do apud AMADO, Jorge Amado: 30 anos de literatura, p. 94.

124 LOBATO, Monteiro apud AMADO, Jorge Amado: 30 anos de literatura, p. 130.

125 Idem.

126 Idem.

127 AMADO, Gilberto apud AMADO, Jorge Amado: 30 anos de literatura, p. 132.

128 Aprofundar debate em: SANTOS, Daiana Nascimento do. Imaginarios literários y políticos en el brasileño Jorge

Amado. New York: Edwin Mellen Press, 2012.

129 BOPP, Raul apud AMADO, Jorge Amado: 30 anos de literatura, p. 131.

130 Idem.

${ }^{131}$ FERRAZ, Aydano do Couto apud AMADO, Jorge Amado: 30 anos de literatura, p. 151. 
do que hoje consideramos como Norte e Nordeste, e reforçaram nos referidos romances um esforço de busca pela gente brasileira. As obras de Amado acabaram representando esses temas nacionais 132 . Jorge Amado escreveu uma primeira leva de romances que tiveram a Bahia como principal cenário, representando um esforço de inserção dos elementos locais e regionais que poderiam ser considerados universais para a maioria dos brasileiros da época, como a incerteza do futuro do país, a miséria, a exploração, prostituição, a dor, o sofrimento e tantos outros. Isso está representado no discurso de Odilo Costa Filho sobre Cacau: "E nenhum livro me faz tanto pensar, olhar para mim mesmo e para nós, Brasil"'133.

Os romances regionalistas de Amado estavam ligados ao movimento de renovação que ganhou maior identidade e solidez com escritores nordestinos como Rachel de Queiroz, José Lins do Rego, José Américo de Almeida, Graciliano Ramos e o próprio Jorge Amado ${ }^{134}$. Segundo Barbosa, como "grande parte destes escritores era proveniente do nordeste, se dá, então, o estabelecimento de uma unidade explicativa de suas obras a partir de uma perspectiva geográfica"135.

Antes mesmo de Barbosa, o escritor e geógrafo pernambucano Josué de Castro alertava-nos no Diário Carioca de 1936, que havia saído "do nordeste resignada, a primeira fornada de verdadeiros romancistas brasileiros. Romancistas chamados de proletários, porque se meteram por lugares escuros onde só os pobres penetram"136. Reiterou que

Foi o clima humano do nordeste que amadureceu o sentido do verdadeiro brasileirismo, na consciência dos intelectuais. É que o nordeste é de todo território brasileiro, a zona que contém maior sentido de tragédia. Keyserling diz que o habitante do deserto tem consciência antes de tudo, do trágico na vida, e o sertanejo do nordeste é habitante dum deserto geográfico e demográfico, vivendo, pois embebido dêste sentido que cria no espírito, uma grande força latente, recalcada. Fôrca que num momento dado pode transformar o sentido trágico num sentido heroico e alcançar supremas realizações. Uma dessas superações. é o novo romance brasileiro, escrito no nordeste..$^{137}$

Era sobre a famosa "geração de 30" que se referia o discurso de Castro, considerada pelos críticos como a que inaugurou, no Brasil, o "romance social". Claro que ainda estava em curso a organização de uma estética, como pode ser notado nos escritos de Amado. Explica Barbosa que os escritores dessa geração "não apresentavam no momento de escrita de suas primeiras obras um sentido de unidade programática como foi o caso, por exemplo, da geração de modernistas que os precedeu"138.

Segundo depoimento de Raquel de Queiroz, na época em que começaram a escrever suas primeiras obras, nenhum dos romancistas que posteriormente seriam agrupados no grupo do "romance nordestino" tinha a intenção de produzir um "romance social": "Nós não tínhamos a intenção de fazer romance de sentido social (...) o que fazíamos era romance-documento, romance-testemunho". Essa firmação de Raquel nos é útil no sentido de indicar como elemento de coesão entre estes novos escritores, sobretudo, a vinculação do narrado a situações observadas em suas realidades específicas. ${ }^{139}$

\footnotetext{
132 Consultar: SANTANA, op. cit.

133 COSTA FILHO apud AMADO, Jorge Amado: 30 anos de literatura, p. 77.

134 Cf. SANTANA, op. cit.

135 BARBOSA, op. cit., p. 107.

136 CASTRO, Josué apud AMADO, Jorge Amado: 30 anos de literatura, p. 115.

137 Idem.

138 BARBOSA, op. cit., p. 107.

139 Idem.
} 
Rachel de Queiroz, Graciliano Ramos, José Américo de Almeida, Armando Fontes, José Lins do Rego, Clovis do Amorim, Cordeiro de Andrade eram alguns dos que compunham um grupo de autores que retrataram o "drama do Nordeste" na literatura, e despertaram a simpatia de Amado pela esquerda. Drama que esteve presente em todo canto do país, e teve, na concepção do autor, suas bases no "latifúndio, na exploração feudalista da terra, e no país que está extremamente atrasado" 140

A ideia do romance-documento ou romance-testemunho gira em torno da ideia de representação da realidade vivida pelos brasileiros em suas especificidades regionais, sendo exatamente isso que Rachel de Queiroz fez em $O$ Quinze para pintar o cenário da seca e da miséria das camadas populares de Fortaleza (Ceará) ${ }^{141}$. O romance da escritora cearense faz referência à grande seca de 1915, quando a autora só tinha cinco anos de idade, forçando sua família a mudar para o Rio de Janeiro em 1917, retornando para o estado de origem apenas dois anos depois. Com esse romance, a autora alcançou aquilo que Castro denominou de "novo romance", preocupado em revelar naquele momento de "compreensão e interpretação humanas, de unificação da inteligência e da sensibilidade brasileiras"142.

Em um artigo publicado pela revista Boletim de Ariel, voltada para as artes e a literatura, Rego referenciou o caráter documental do quarto romance de Amado:

"Jubiabá" é um livro que fala com uma eloqüência formidável da desgraça, do sofrimento de uma humanidade que Deus esqueceu pelos morros e pelas plantações de fumo da Bahia. Neste sentido o romance é, incontestavelmente, um documento dos mais dolorosos expostos às vistas do mundo (grifo nosso). Que existe um inferno na terra ninguém poderá duvidar. Procure-se a Bahia de Jubiabá para se entrar em contacto com uma gente que foi ao extremo do pauperismo, na terra que os cronistas pintavam com o mel e as frutas do paraíso. ${ }^{143}$

O escritor e historiador Octávio ${ }^{144}$ Tarquinio de Souza observou que o caráter documental de Jubiabá está nas várias observações em torno de fatos, acontecimentos, espetáculos e coisas vividas que remetem a um plano "que não será irreal mas não é seguramente o da realidade quotidiana e vulgar"145. E acrescentou, que pode "Jubiabá ser um negro de verdade, eleitor, segundo me afirmaram, do ilustre deputado Homero Pires; podem muitas das personagens que aparecem no livro ter existência real, observadas pelo romancista nas suas 'colheitas de material'. Não importa! "146

Acreditamos que existe muita coesão nos discursos dos comunistas sobre o romancedocumento. O escritor comunista Aderbal Jurema, em um artigo publicado pelo Boletim de Ariel, em 1934, fez uma análise interessante do romance Suor e chegou a afirmar com muita convicção que não se tratava apenas de um texto literário, porque era "antes, porém, um documento vivo e impressionante do proletariado urbano da cidade de São Salvador" 147.

Os romances regionalistas foram articulados "pela grande preocupação em representar, quase sem intermediação, aspectos da sociedade brasileira na forma de narrativa que beiram a reportagem ou o estudo sociológico"148. Segundo reflexão de Portella, Jorge Amado foi um dos poucos escritores

\footnotetext{
140 RAILLARD, op. cit., p. 48 e 74.

141 Sobre este aspecto consultar: DUARTE, op. cit., p. 66, 73 e 83.

142 CASTRO apud AMADO, Jorge Amado: 30 anos de literatura, p. 115.

143 REGO apud AMADO, Jorge Amado: 30 anos de literatura, p. 94.

${ }_{144}$ Estamos mantendo da mesma forma que o autor assina o artigo.

145 SOUZA, Octávio Tarquinio de apud AMADO, Jorge Amado: 30 anos de literatura, p. 97.

146 Idem.

147 JUREMA, Aderbal apud AMADO, Jorge Amado: 30 anos de literatura, p. 91

148 CALIXTO, Carolina Fernandes. Jorge Amado e a identidade nacional: diálogos políticos-culturais. 2011. p. 72. Dissertação (Mestrado em História) - Universidade Federal Fluminense, Niterói, 2011.
} 
regionalistas que soube fazer uso do "documento sociológico em detrimento do testemunho ou da realização artística" 149 .

A busca por dados empíricos nos escritos literários aproximou muitos desses autores à figura do antropólogo. Foi o caso de Jorge Amado que "empreendeu diversas viagens pelo sertão da Bahia e diferentes regiões do Nordeste com o objetivo de "coletar material"' 150 . Para Portella, "No caso dos romancistas do Nordeste, este apego ao 'real' se apresentava de maneira ainda mais acentuada porque muitos intelectuais identificaram nesta região uma concentração dos principais problemas da sociedade brasileira". 151

Dos estados nordestinos, os regionalistas buscavam por temas universais que atendessem à demanda de descrição da "alma do Brasil" e de seus problemas econômicos, sociais e culturais. Assegura Portela, que Amado "soube perfeitamente compreender, assimilar e valorizar essas manifestações locais ou regionais de vida e de cultura"152.

\section{REFERÊNCIAS}

AMADO, Jorge. O país do carnaval. Rio de Janeiro: Record, 1980. , Jorge. Cacau. Rio de Janeiro: Record, 1981.

, Jorge. Suor. Rio de Janeiro: Record, 1981.

, Jorge. Jubiabá. Rio de Janeiro: Record, 1981.

, Jorge. Mar morto. Rio de Janeiro: Record, 1980.

, Jorge (Org.). Jorge Amado: 30 anos de literatura. São Paulo: Livraria Marins Editoria, 1961.

, Jorge; GOMES, Alvaro Cardoso. Jorge Amado. São Paulo: Abril Educação, 1981.

BARBOSA, Júlia Monnerat. Militância política e produção literária no Brasil (dos anos 30 aos anos 50): as trajetórias de Graciliano Ramos e Jorge Amado e o PCB. 2010. 403 f. Tese (Doutorado em História) - Universidade Federal Fluminense, Niterói, 2010.

CALIXTO, Carolina Fernandes. Jorge Amado e a identidade nacional: diálogos políticos-culturais. 2011. 171 f. Dissertação (Mestrado em História) - Universidade Federal Fluminense, Niterói, 2011.

CANTALINO, Maria das Graças Nunes; ANDRADE, Ricardo Henrique Resende de. Lenita: um livro não amado. Entrelaçando: Revista Eletrônica de Culturas e Educação, Amargosa, v. 1, n. 1, p.109-118, out. 2010.

CARNEIRO, Edison. Uma toada triste vem do mar. O Jornal, Rio de Janeiro, p. 3, 24 nov. 1935.

CARNEIRO, Edison. Notas sobre "Suor". O Jornal, Rio de Janeiro, p. 3, 21 out. 1934.

CUNHA, Betina Ribeiro Rodrigues da. Poeticas da negritude e da exclusão em Jorge Amado. Izquierdas, Santiago de Chile, n. 32, p. 172-183, mar. 2017.

DALMÁS, Carine. Frentismo cultural dos comunistas no Brasil e no Chile: literatura, escritores e virada aliancista (1935-1936). Projeto História, São Paulo, n. 47, p. 225-258, ago. 2013.

Diário de Notícias, Rio de Janeiro, p. 4, 20 nov. 1931.

Diário da Manhã, Espírito Santo, p. 1, 21 jan. 1932.

DIAS, Fabio Alves dos Santos. Do realismo burguês ao realismo socialista: um estudo sobre a questão da herança cultural no pensamento de Lukács nos anos 1930. 2014. 250 f. Tese (Doutorado em Sociologia) - Universidade de São Paulo, São Paulo, 2014.

149 PORTELLA, Eduardo. A fábula em cinco tempos. In: AMADO, Jorge. Jorge Amado: 30 anos de literatura. São Paulo: Livraria Marins Editoria, 1961. p. 13.

150 CALIXTO, op. cit., p. 72.

151 PORTELLA, op. cit., p. 13.

152 Ibidem, p. 14-15. 
DUARTE, Eduardo de Assis. Jorge Amado: romance em tempo de utopia. Natal: Editora da UFRN, 1995.

FONTES, Rafael Oliveira. A Seiva de uma juventude: intelectualidade, juventude e militância política (salvador, Bahia, 1932-43). 2011. 164 f. Dissertação (Mestrado em História) - Universidade Estadual de Feira de Santana, Feira de Santana, 2011.

GOLDSTEIN, Ilana Seltzer. O Brasil Best Seller de Jorge Amado: literatura e identidade nacional. São Paulo: Editora SENAC, 2003.

LUKÁCS, Georg. Ensaios sobre literatura. Rio de Janeiro: Editora Civilização Brasileira, 1965.

MARIÁTEGUI, José Carlos. Revolução Russa: história, política e literatura. São Paulo: Expressão Popular, 2012.

NAPOLITANO, Marcos. A relação entre arte e política: uma introdução teórico-metodológica. Temáticas, Campinas, v. 37, n. 38, p.25-56, 2011.

OLIVEIRA, Olivia Fernandes de. Notas sobre algumas páginas mais ou menos modernas. O 'Modernismo' na Bahia através das Revistas. RUA. Revista de Arquitetura e Urbanismo, Salvador, v. 7, p. 12-23, 1999.

O Imparcial, Rio de Janeiro, p. 2, 23 out. 1931.

PALAMARTCHUK, Ana Paula. Ser intelectual comunista: escritores brasileiros e o comunismo (1920-1945). 1997. 172 f. Dissertação (Mestrado em História) -Universidade Estadual de Campinas, Campinas, 1997.

Os novos bárbaros: escritores e comunismo no Brasil (1928-1948). 2003. 367 f. Tese (Doutorado em História) - Universidade Estadual de Campinas, Campinas, 2003.

PIEMONTE, Víctor Augusto. El realismo socialista, la Tercera Internacional y el giro politico-cultural en el comunismo argentino. In: Jornadas de Sociología de la UNPL, 7, 2012, Argentina. Anais Eletrônicos... Argentina: UNPL, Argentina. p.1-23. Disponível em: http://www.memoria.fahce.unlp.edu.ar/trab_eventos/ev.2189/ev.2189.pdf. Acesso em: 23 abr. 2017. PORTELLA, Eduardo. A fábula em cinco tempos. In: AMADO, Jorge. Jorge Amado: 30 anos de literatura. São Paulo: Livraria Marins Editoria, 1961. p. 13-26.

QUEIROZ, Rachel de. O quinze. Rio de Janeiro, José Olympio, 2004.

RAILLARD, Alice. Conversando com Jorge Amado. Rio de Janeiro: Record, 1992.

ROSSI, Luiz Gustavo Freitas. O intelectual “feiticeiro": Édison Carneiro e o campo de estudos das relações raciais no Brasil. 2011. 221 f. Tese (Doutorado em Antropologia) - Universidade Estadual de Campinas, Campinas, 2011.

SANTANA, Geferson. O combate das ideias: estratégias culturais dos intelectuais comunistas baianos na produção de um novo conhecimento sobre o Brasil (1920-1937). 2017. 336 f. Dissertação (Mestrado em História) - Universidade Federal de São Paulo, Guarulhos, 2017.

SANTOS, Daiana Nascimento dos. El realismo socialista en tierras tupiniquines. Pacarina del Sur, ano 5, n. 21, out./dez., 2014. Disponível em: http://pacarinadelsur.com/home/figuras-e-ideas/1030el-realismo-socialista-en-tierras-tupiniquines. Acesso em: 21 jul. 2018.

Daiana Nascimento dos. Hoz, martillo, resistencia, sudor y pueblo en el brasileño Jorge Amado. In: CUNHA, Betina Ribeiro Rodrigues da; REIS, Carlos (Orgs.). Amado Jorge: um retrato de muitas faces. Rio de Janeiro: Bonecker, 2018. p. 39-44.

Daiana Nascimento dos. Comunismo y Novela en el brasileño Jorge Amado. Izquierdas, Santiago de Chile, ano 3, n. 6, p. 1-5, 2010.

SECCO, Lincoln. Leituras comunistas no Brasil (1919-1943). In: DEAECTO, Midori; MOLLIER, Jean-Yves (Orgs.). Edição e revolução: leituras comunistas no Brasil e na França. Cotia, São Paulo: Ateliê Editorial; Belo Horizonte, Minas Gerais: Editoria UFMG, 2013, p. 29-64.

SILVA, Paulo Santos. Âncora de tradição: luta política, intelectualidade e construção do discurso histórico na Bahia (1930-1945). Salvador: EDUFBA, 2000. 
SOARES, Ângelo Barroso Costa. Academia dos Rebeldes: modernismo à moda baiana. 2005. 207 f. Dissertação (Mestrado em Literatura e Diversidade Cultural) - Universidade Estadual de Feira de Santana, Feira de Santana, 2005.

SODRÉ, Nelson Werneck. Pinheiro Viegas. Correio Paulistano, São Paulo, p.13, 28 mai. 1939.

TÁTI, Miécio. Jorge Amado: vida e obra. Belo Horizonte: Editoria Itatiaia Limitada, 1961.

ZHDANOV, Andrei. Soviet Literature - Richest in Ideas, Most Advanced Literature. In: Gorky, Radek, Bukharin, Jdanov and others "Soviet Writers' Congress 1934", Lawrence \& Wishart, 1977. Transcribed by Jose Braz, Andy Blunden and Hasan. Oline version. Disponível em: https://www.marxists.org/subject/art/lit_crit/sovietwritercongress/index.htm. Acesso em: 20 de ago. 2016. 